\title{
Politics fuels French synchrotron row
}

[PARIS] The last days of France's outgoing conservative coalition government have been marked by a row over the siting of France's planned FFr1-billion (US\$174-million) $2.15-\mathrm{GeV}$ synchrotron, with rumours that the government intended to forgo the formal selection procedure and site the facility in Bordeaux, whose mayor is the former prime minister Alain Juppé.

Following last weekend's election victory by the left-wing parties, Claudine Laurent, a member of the Socialist party's committee on science, says that the decision on the siting of the SOLEIL synchrotron will be reviewed from scratch.

Several cities are bidding to host SOLEIL. Among the favourites is Paris, whose region is already home to the LURE facilities (800 $\mathrm{MeV}$ and $1.85 \mathrm{GeV}$ ) - which SOLEIL is intended to replace - and which possesses the appropriate staff and technical experience, as well as a cluster of service companies.

At the same time, France is keen to decentralize its research (see Nature 356, 373; 1992), and strong contenders include Caen, Lille, Marseilles and Orléans - even though a new site outside Paris would greatly increase costs because of the need to hire new staff and build up local skills.

A late entry has been the city of Bordeaux. Both the research ministry and Matignon, the prime minister's residence, deny claims, first made in the newspaper Libération, that the government was considering choosing Bordeaux. But many feel there is strong circumstantial evidence to the contrary.

For example, although most candidates have spent months - if not years - preparing their applications, Bordeaux's was hurriedly put together within three weeks at the end of April.

Furthermore, siting bids for research facilities are normally submitted to the government by scientists and locally elected officials. But the Bordeaux bid was put in directly by the préfet of the region, who represents the government, and who called a meeting of local scientists in April in order to draw up the bid.

Last month's hurriedly called election has delayed an expected announcement by the government that it had approved the construction of SOLEIL. But the choice of a site is not expected until next year, as this requires a detailed assessment of the scientific and technical merits of tenders, as well as their feasibility and cost-effectiveness.

Although the final decision on big science facilities - which is formally the responsibility of the prime minister's office - tends inevitably to contain a substantial political component, scientists are keen that the assessment phase itself should not be rushed.

The National Union of Scientific Researchers last week condemned any premature decision to site the synchrotron in Bordeaux, claiming that this would be blatant political interference in the necessary consultation procedure. It urged the scientific community to "react immediately by letters, petitions and telegrams to the prime minister and president of the Republic" to

\section{France and Britain drop idea of joint machine}

[PARIS] The prospect of France and the United Kingdom abandoning their planned national second-generation synchrotrons - SOLEIL and DIAMOND respectively - in favour of jointly constructing a single machine (see Nature $381,100 ; 1996)$ has been definitively dropped.

David Norman, who took over this week as head of synchrotron radiation at the Daresbury laboratories in Cheshire, says that it has been agreed that the size of the user communities in each country justifies each building its own machine.

"Synchrotron radiation is now just part of the everyday tool kit of many scientists, and is no longer just the frontier research tool for the few," says Norman, who took over from lan Munroe, who has retired.

Instead, Britain, France and Switzerland - which plans to build the $2.1-\mathrm{GeV}$ Swiss Light Source - will coordinate the construction of their respective synchrotrons to reduce costs and overlap. A tripartite agreement setting out the terms of such collaboration is about to be signed.

This will identify areas for cooperation, such as the joint design of components, the standardization of materials and procedures, and bulk purchasing. The agreement also addresses concern that the simultaneous construction of three large synchrotrons could outstrip the capacity of European industry.

The deal will grant researchers reciprocal access to one another's beamlines. The 3-GeV DIAMOND machine produces harder X-rays than the Swiss and French machines, and is more suited to studying biological structures. Softer $\mathrm{X}$-rays are better for determining electronic structure and spectroscopy.

The French government is expected to approve SOLEIL soon (see above), and the Swiss project is in the final stages of approval. John Cadogan, directorgeneral of the UK research councils, this week submitted the full case for DIAMOND to the councils for comment. D.B.

\section{IMAGE UNAVAILABLE FOR COPYRIGHT REASONS}

Where now? Former prime minister Alain Juppé is mayor of Bordeaux, which has bid for SOLEIL. head off any such attempt.

"We wanted to put out the fire before it started, as it is always more difficult to stop afterwards," says François Wuilleumier, director of the Laboratory of Atomic and Ionic Spectroscopy at the Université ParisSud, one of the partners in the Ile-de-France region's bid for SOLEIL.

Indeed, Wuilleumier believes that the quick reaction of the scientific community made any premature choice of Bordeaux politically impossible. Concern has further subsided following the victory of the left in last weekend's general election, but some warn that vigilance is still required, as the presidential office could impose a decision.

One scientist who helped to draft the Bordeaux bid accepts that Juppé's presence has given Bordeaux a political edge on its rivals. But he argues that the project is scientifically sound, and points out that the Bordeaux dossier incorporates an earlier bid from nearby Toulouse, as part of a joint candidature for the Aquitaine region.

"An outsider knowing nothing of French politics would consider Bordeaux a strong candidate," he claims, arguing that the planned FFr6-billion 1.8-megajoule laser (see Nature 375, 6; 1995) near the city makes it the ideal choice as a 'pole' for high-power radiation research facilities.

Grenoble has already achieved this over the past twenty-five years, being home to the Institut Laue-Langevin neutron source and the European Synchrotron Radiation Facility, as well as a host of associated laboratories. One senior official at the Commisariat à l'Energie Atomique says, however, that it would be difficult to imagine siting an open civil facility such as SOLEIL next to the top-secret military megajoule installation near Bordeaux. 